\title{
Pathogen Dispersal and Glomerella Leaf Spot Progress Within Apple Canopy in Brazil
}

\author{
Natasha Akemi Hamada, ${ }^{1}$ Rafaele Regina Moreira, ${ }^{1}$ Cristiano Nunes Nesi, ${ }^{2}$ and Louise Larissa May De Mio ${ }^{1, \dagger}$ \\ ${ }^{1}$ Universidade Federal do Paraná, Setor de Ciências Agrárias, Curitiba, PR 80035-050, Brazil \\ ${ }^{2}$ Empresa de Pesquisa Agropecuária e Extensão Rural de Santa Catarina (Epagri), Chapecó, SC 89801-970, Brazil
}

\begin{abstract}
Glomerella leaf spot (GLS) of apple is caused by three different Colletotrichum species complexes. This study evaluated the dispersal of Colletotrichum spores related to GLS temporal progress and defoliation. Spores were monitored by air and water runoff in different plant heights,

source of primary inoculum. In plots with high primary inoculum, the disease increases exponentially during favorable weather conditions. The highest initial inoculum was found in the lower part of the tree, but the highest rate of the disease progress in the upper.
\end{abstract} and the temporal progress of GLS and defoliation were assessed. Spores of the pathogen were first cached in the lower part of the tree closer to the ground, confirming the importance of dead leaves on the ground as main

Keywords: disease development and spread, disease management, epidemiology, fruit, fungi, tree fruits

Glomerella leaf spot (GLS) in apple is an important disease in the United States, Brazil, and China (Leite et al. 1988; Taylor 1971; Wang et al. 2012). The species reported as causal agents in South America (Brazil and Uruguay) belong to the complexes Colletotrichum gloeosporioides, Colletotrichum acutatum, and Colletotrichum boninense (Moreira et al. 2019; Velho et al. 2015). The Colletotrichum species complex distribution in Brazil varies among apple-producing states; for example, for Santa Catarina State, the main complex is $C$. gloeosporioides, and for Paraná State, it is C. acutatum (Moreira et al. 2019). GLS occurs in all production regions in Brazil, causing severe damage to the cultivar Gala and its clones, which correspond to $60 \%$ of the commercial production area (Petri et al. 2011).

Spraying with fungicides from the methyl benzimidazole carbamates and dithiocarbamates groups is the most used method to control GLS in Brazil (Katsurayama and Boneti 2009). However, these fungicides lose much of their efficiency under high inoculum pressure. In warmer regions, such as in Paraná State, fungicide applications are performed at 5- to 10-day intervals or repeated when cumulative rainfall reaches $25 \mathrm{~mm}$, which results in a high number of fungicide applications (Becker et al. 2000). In some regions with less favorable climate to GLS development, chemical control is based on weather monitoring (Becker et al. 2004), and intervals are extended. Even with intense use of fungicides, the disease may begin in late spring, with severe symptoms development in the summer when frequent rains and high temperatures favor the disease (Hamada et al. 2012). During harvest, which occurs in January and February in southern Brazil, the application of fungicides is avoided because of the preharvest interval, thus increasing the risk of new infections.

Symptoms of GLS mainly occur on leaves, although they may also appear on fruit. On leaves, symptoms appear as purple-red spots 2 days after infection, and after 7 to 10 days, severe defoliation

${ }^{\dagger}$ Corresponding author: L. L. May De Mio; maydemio@ufpr.br

Funding: This work was supported by Conselho Nacional de Desenvolvimento Científico e Tecnológico grant 483566/2013-6.

The author(s) declare no conflict of interest.

Accepted for publication 2 May 2019.

○ 2019 The American Phytopathological Society may occur (Leite et al. 1988; Moreira and May De Mio 2015), reducing productivity in the subsequent seasons. Considering the short incubation period of GLS and rapid advance of the disease, it is essential to understand the disease epidemiology to establish adequate management. Strategies for integrated management of diseases are recommended by the researchers in Santa Catarina State, and they included monitoring the meteorological variables to pinpoint the infection process and spore dispersal (Becker et al. 2004). However, in Paraná State, where GLS is more severe owing to the high pressure of inoculum, these strategies are not efficient to achieve the control of GLS.

Spore dispersal in Colletotrichum spp. usually occurs by rain splash and travels short distances as already reported in coffee (Mouen Bedimo et al. 2007), strawberry (Freeman et al. 2002; Madden et al. 1996), and yam (Penet et al. 2014). However, in some pathosystems, the dispersion of Colletotrichum spp. may also occur by the action of other agents, such as insects and air currents (SilvaJunior et al. 2014).

GLS has been present in Paraná State since 1988, but some basic information regarding its epidemiology to minimize its yieldreducing effects is still lacking. There is limited information available on GLS temporal progress and no information about the relationship between the inoculum dispersal, primary inoculum, and disease within the apple canopy. In this study, we assessed the dispersal of Colletotrichum spp. spores by runoff and air at different heights of the plant and the temporal progress of GLS in the leaves of shoots at different plant heights, exploring its relation to defoliation and dispersal patterns.

\section{Materials and Methods}

Description of study plots, population isolates, and meteorological conditions. The tests were carried out during the 2009/2010, 2010/2011, and 2011/2012 growing seasons. Three plots were evaluated: two being in the same commercial orchards with use of fungicides (A1 and A2) and an experimental one without use of fungicides (A3). The trees in plots A1 and A2 were 13-year-old cultivar Imperial Gala grafted on rootstock M9 with a central leader system. The spacing in A2 was $4.0 \times 0.75 \mathrm{~m}$. In A1, spacing was $3.3 \times 1 \mathrm{~m}$; however, there were double rows with $2.2 \mathrm{~m}$ between them. In A3, plants were 7-year-old Gala grafted on rootstock M9 with a central leader system, and spacing was $2.5 \times 1.0 \mathrm{~m}$.

The plots were located in the metropolitan region of Curitiba, Paraná State at the same altitude ( $\sim 930 \mathrm{~m}$ in relation to sea level) and under the same type of climate. The A1 and A2 were located in the same 

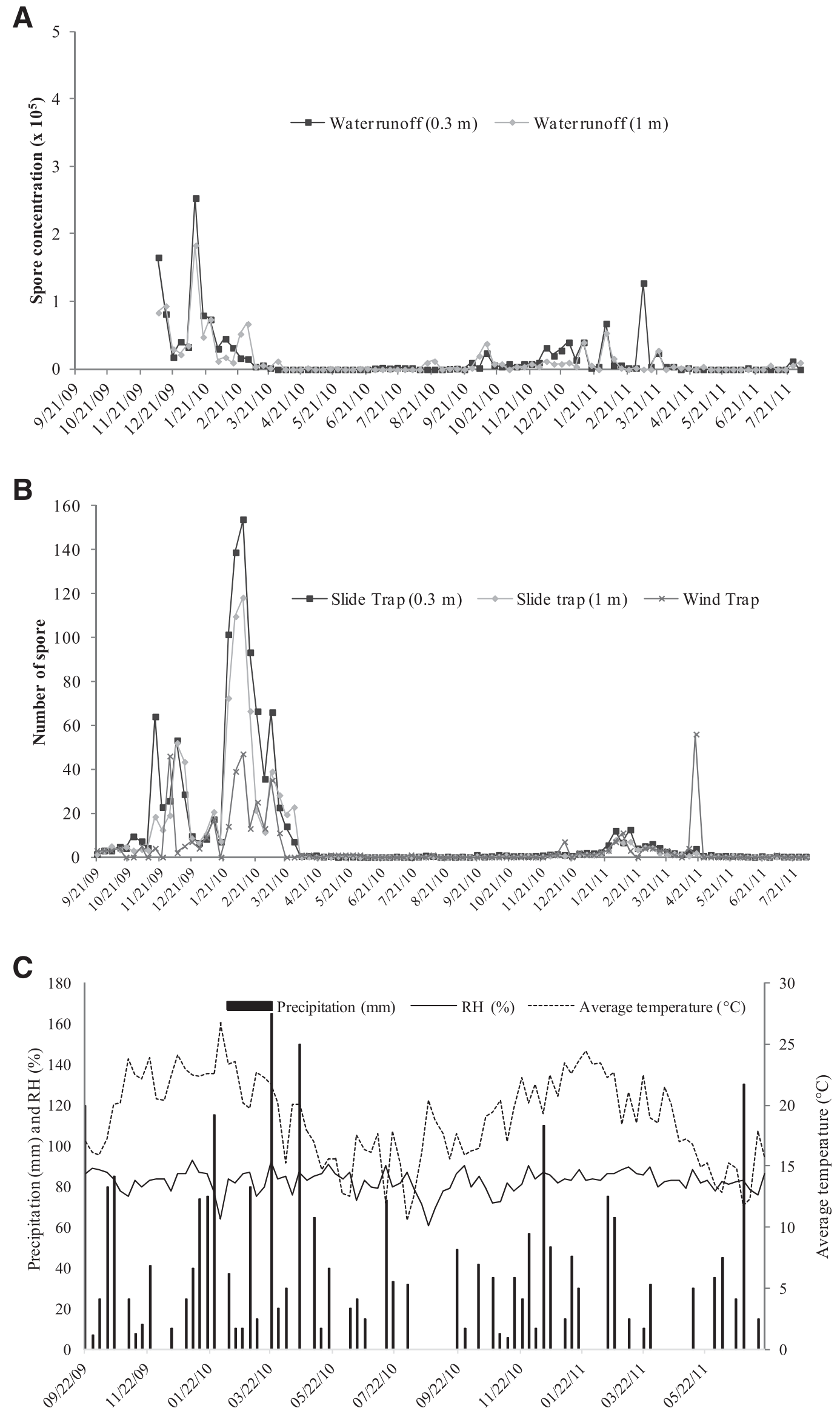

Fig. 1. A, Colletotrichum spp. conidia concentration obtained from water runoff on the plant surface at 0.3 and $1.0 \mathrm{~m}$. B, The number of conidia of Colletotrichum spp. collected on each evaluation day with wind traps positioned at $0.3,1.0$, and $2.5 \mathrm{~m}$ from the ground. C, Precipitation (millimeters), average RH, and average temperature. Weekly data for the 2009/2010 and 2010/2011 seasons were collected in a commercial orchard in the municipality of Campo Largo, Paraná (A1). 


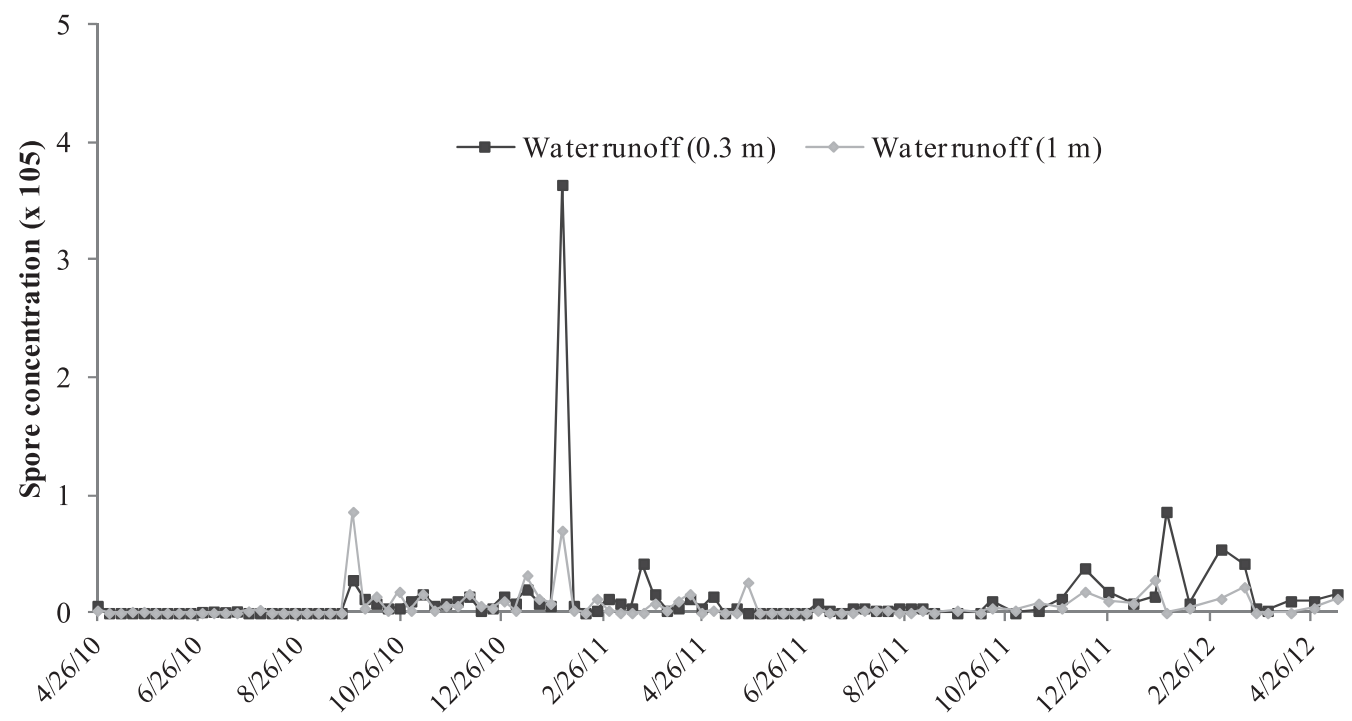

B
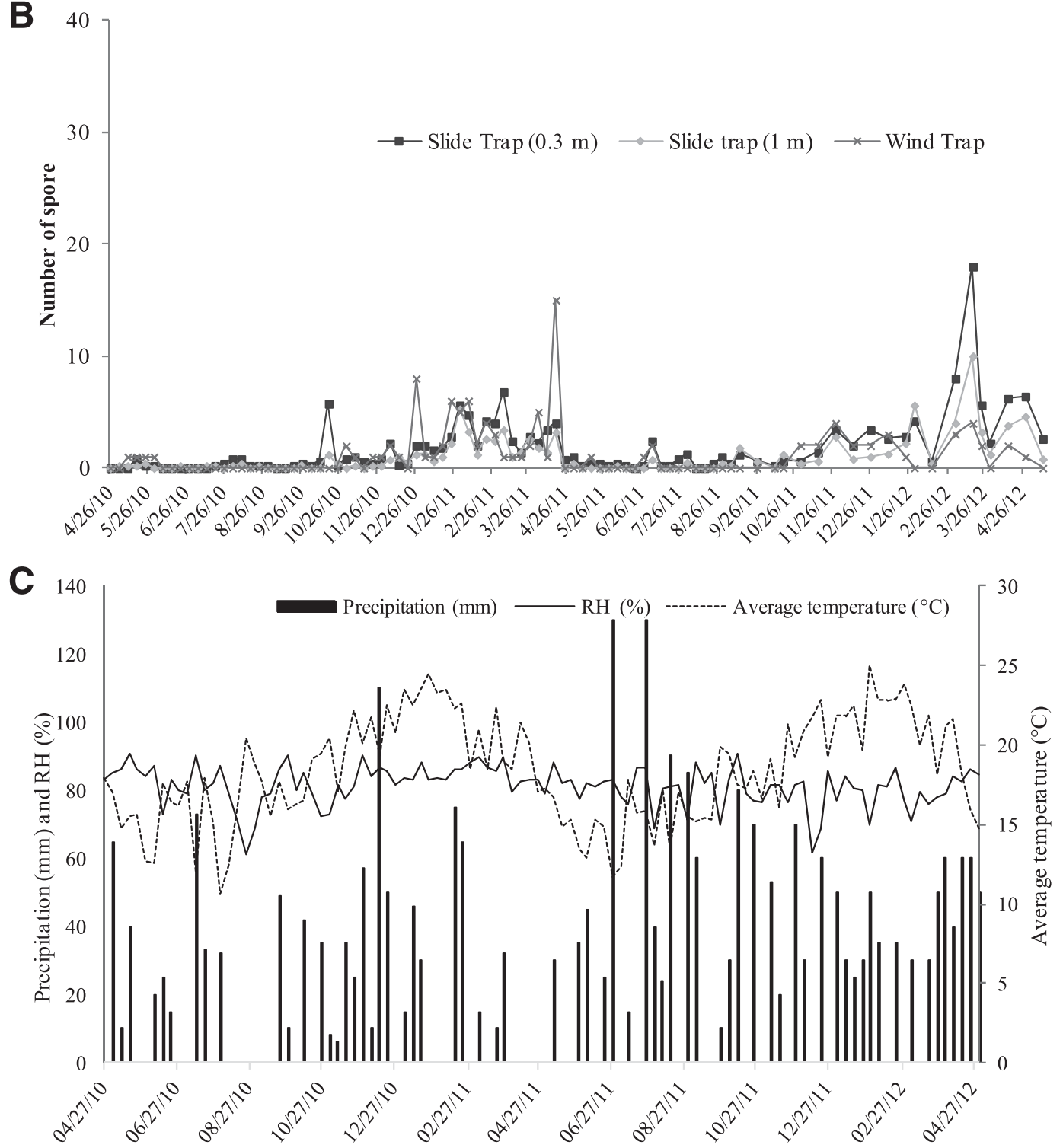

Fig. 2. A, Colletotrichum spp. conidia concentration obtained from water runoff on the plant surface at 0.3 and $1.0 \mathrm{~m}$. B, The number of conidia of Colletotrichum spp. collected on each evaluation day with wind traps positioned at $0.3,1.0$, and $2.5 \mathrm{~m}$ from the ground. C, Precipitation (millimeters), average RH, and average temperature. Weekly data for the 2010/2011 and 2011/2012 seasons were collected in a commercial orchard in the municipality of Campo Largo, Paraná (A2). 

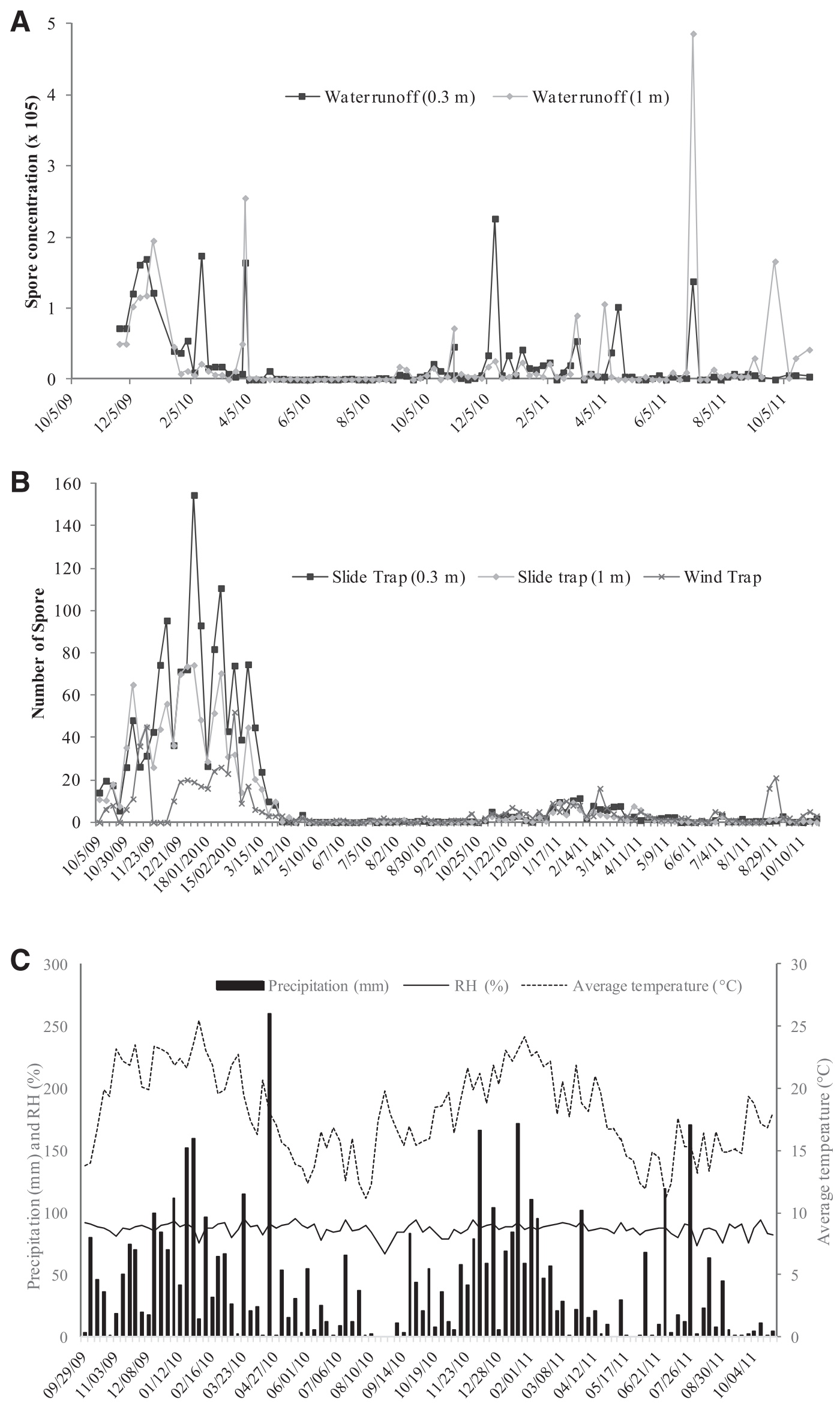

Fig. 3. A, Colletotrichum spp. conidia concentration obtained from water runoff on the plant surface at 0.3 and $1.0 \mathrm{~m}$. B, The number of conidia of Colletotrichum spp. collected on each evaluation day with wind traps positioned at $0.3,1.0$, and $2.5 \mathrm{~m}$ from the ground. $\mathrm{C}$, Precipitation (millimeters), average RH, and average temperature. Weekly data for the 2010/2011 and 2011/2012 seasons were collected in a commercial orchard in the municipality of Pinhais, Paraná (A3). 
orchard in the municipality Campo Largo $\left(25^{\circ} 25^{\prime} 20^{\prime \prime} \mathrm{S}, 49^{\circ} 32^{\prime} 36^{\prime \prime} \mathrm{W}\right)$, and A 3 was located in the municipality of Pinhais $\left(25^{\circ} 23^{\prime} 16^{\prime \prime} \mathrm{S}\right.$, $\left.49^{\circ} 07^{\prime} 56^{\prime \prime} \mathrm{W}\right)$. The plots A1 and A2 are $40 \mathrm{~km}$ from plot A3 in a straight line. In the 2009/2010 season, the areas A1 (fungicide sprayed) and A3 (no fungicide) were chosen to compare the dispersion of spores in areas with and without fungicide. In the 2010/2011 season, A2 (fungicide sprayed) was included (the same property as A1) mainly because of the high inoculum present in A1. In the 2011/2012 season, only A2 was evaluated, because A1 (fungicide sprayed) and A3 (no fungicide) were eradicated because of the high severity of the disease.

The pathogen population ( $n=47$ isolates) was previously characterized (Moreira et al. 2019), and the predominant species was Colletotrichum nymphaeae (81\%); Colletotrichum fructicola (seven isolates), Colletotrichum paranaense (one isolate), and Colletotrichum limetticola (one isolate) were also detected.

Fungicide applications were carried out in A1 and A2 according to the recommended spray calendar in the region following the standards of integrated apple production in Brazil (NTEPI 2006).

Data of temperature and RH were obtained from the meteorological stations of the SIMEPAR Technological Institute. For A1 and A2, data were collected at meteorological station number 25.264.916 located in Curitiba at an altitude of $935 \mathrm{~m}$ and a distance of $31 \mathrm{~km}$ from the study orchards. For A3, data were collected at meteorological station number 25.254.905 located in Pinhais at an altitude of $930 \mathrm{~m}$ and a distance of $21 \mathrm{~km}$ from the study orchard. Precipitation was quantified daily in the orchards by the use of a pluviometer (JProlab).

The number of favorable days (FDs) for the occurrence of GLS was calculated according to the method proposed by Katsurayama et al. (2000) in apple, which considers an FD to be one with a leaf wetness period (LWP) $>10 \mathrm{~h}$ and a temperature $>15^{\circ} \mathrm{C}$. The LWP during the vegetative period of the plants in the evaluated seasons was estimated using the number of hours with an $\mathrm{RH}>87 \%$ (SIMEPAR), which is based on the fact that the presence of liquid water on the surface is generally related to high values of RH (Gleason et al. 1994).

Spore dispersal from the trunk of the tree. Eppendorf tubes (1.5-ml volume) were fixed to the trunk of the tree at 0.3 and $1.0 \mathrm{~m}$ from the ground with their lids open for the collection of runoff water. The contact area between the Eppendorf tube and the trunk of the tree corresponded to $\sim 0.5 \mathrm{~cm}$, and there were no situations where we observed that liquid overflowed. The tubes were collected weekly in the 2009/2010 and 2010/2011 growing seasons and biweekly in the $2011 / 2012$ season.

The number of spores was quantified according to the methodology described by Estrada et al. (1996); samples were centrifuged at 3,000 rpm for $5 \mathrm{~min}$, and the supernatant was discarded. The formed pellet was resuspended in $100 \mu$ l of distilled water, and the spore concentration was determined using a hemocytometer. Five replicates (each tree constituted one replicate) were evaluated in each sampled plot. Each randomized sampled tree distance from each other was 7 to $10 \mathrm{~m}$.

Spore dispersion from the air. The test for air dispersal of spores was carried out uninterrupted throughout the specific growing seasons. Monitoring of the spore density was carried out with the installation of one slide trap per replicate at two different tree heights: 0.3 and $1.0 \mathrm{~m}$ from the ground. Five replicates per height (each tree constituted one replicate) were evaluated in each sampled plot.

The traps consisted of microscopic slides $(26 \times 76 \mathrm{~mm})$ containing Vaseline on their surface, which were placed under a plastic cover (similar to a small umbrella) to prevent rain or even excessive dew from removing the collected spores. The trap slides were suspended vertically from the tree branch with a string to enable the slide to move according to air flow, simulating a leaf.

In addition, one wind-catcher spore trap was installed in each evaluated plot. They were made of Vaseline-coated microscope glass slides placed vertically inside an open cylinder that moved with the wind direction, and they were placed at a height of $2.5 \mathrm{~m}$ from the ground. For each slide (and the other slides discussed above), an area of $25 \mathrm{~mm}^{2}$ was scanned with a microscope (100x; Olympus; model CX40), and the total number of Colletotrichum spores was counted. In the first two seasons (2009/2010 and 2010/2011), the slides were changed weekly, and in the 2011/2012 season, they were changed every 2 weeks.

Data analysis. The area under the progress curve (AUPC) for spore density of Colletotrichum spp. was calculated separately for spores collected by air and water runoff. The values were expressed in a relative way: that is, they were expressed as AUPC divided by the number of days during each evaluation period of the plots. The experiment followed the completely randomized design, and the number and concentration of spores captured at different heights within the same plot were compared as well as the number and concentration of spores captured at the same height in different plots to confirm differences of primary inoculum among plots (A1, A2, and A3).

The data, when necessary, were transformed according to the Box-Cox method (Box and Cox 1964) to meet the assumptions of analysis of variance analysis and subjected to a means separation test (Scott-Knott, $\alpha=0.05$ ). The analyses were performed using software R (R Core Team 2016).

Temporal progression of GLS in the leaves of shoots at different plant heights. To verify the temporal progression of the disease, plants were analyzed in plots $\mathrm{A} 1$ and $\mathrm{A} 2$ during consecutive seasons. In the 2010/2011 season, plots A1 and A2 were evaluated; in the 2011/2012 season, only A2 was evaluated. We did not assess disease in A3; the plants were weak, and the leaves fell down early in the season, even with low GLS severities.

In the 2010/2011 and 2011/2012 seasons, five plants were sampled in each of the two plots (A1 and A2), avoiding pollinating plants. In each plant, three shoots (one shoot per height) containing 10 leaves located at three heights on the plant were evaluated. Low shoots were those located in the lower third of the plant $\sim 0.3 \mathrm{~m}$ from the ground, and the medium shoots were those located in the middle third of the plant $\sim 1.0 \mathrm{~m}$ from the ground; the upper shoots were those located in the upper third of the plant $\sim 1.8 \mathrm{~m}$ from the ground.

The shoots at each height were chosen at random from the plant canopy, but they were always new shoots that had developed from that season, with leaves of similar ages. An interval of 10 leaves was marked with indicator tape at both ends of the shoot so that no shoots emerging after the beginning of the evaluations were considered. The evaluation of the leaves was always performed from the base to the apex of the shoot.

The GLS incidence, severity, and number of leaves were evaluated weekly until all of the leaves had fallen from the shoot. For incidence,

Table 1. Area under the curve progress formed by the density of the conidia of Colletotrichum spp. collected in the air and superficial water runoff with different traps models positioned at different heights from the ground during the 2009/2010, 2010/2011, and 2011/2012 seasons in apple orchards with (A1 and $\mathrm{A} 2$ ) and without (A3) chemical fungicide treatment

\begin{tabular}{|c|c|c|c|c|}
\hline \multirow[b]{2}{*}{ Trap design } & \multirow{2}{*}{$\begin{array}{l}\text { Height of the } \\
\text { trap from the } \\
\text { ground, } m\end{array}$} & \multicolumn{3}{|c|}{ Area under the curve progress ${ }^{x}$} \\
\hline & & A1 & A2 & A3 \\
\hline $\begin{array}{l}\text { Eppendorf (water } \\
\text { runoff) }\end{array}$ & 0.30 & $0.158 a A$ & $0.124 a A$ & $\overline{0.213 a A}$ \\
\hline $\begin{array}{l}\text { Eppendorf (water } \\
\text { runoff) }\end{array}$ & 1.00 & $0.123 a A$ & $0.062 b B$ & $0.222 a A$ \\
\hline Slide trap & 0.30 & $10.258 \mathbf{a A}^{\mathrm{y}}$ & $1.894 \mathbf{a B}$ & $11.072 \mathbf{a A}$ \\
\hline Slide trap & 1.00 & $7.658 \mathbf{b A}$ & $1.126 \mathrm{bB}$ & $6.208 \mathbf{b A}$ \\
\hline Wind trap & 2.50 & $4.403^{z}$ & 1.254 & 5.390 \\
\hline
\end{tabular}

$\mathrm{x}$ The values for the evaluation time (simple daily average) are as follows. The periods of evaluation for the wind trap in A1, A3, and A3 were 686, 742, and 756 days, respectively, and the periods of evaluation for dissemination by water runoff in A1, A2, and A3 were 602, 742, and 707 days, respectively. y Averages followed by the same lowercase letter in the column and the same capital letter in the row do not differ significantly based on the Scott-Knott test $(\alpha=0.05)$. Italic letters compare the Eppendorf trap, and bold letters compare the slide trap. Original data are without transformation. Comparisons between the values were observed in the same trap design.

${ }^{\mathrm{z}}$ Not considered in the means separation test, because there were no repetitions of these traps at this point in the same plot. 
the percentage of leaves with any symptoms of the disease was calculated in relation to the total number of leaves. For the severity assessments, a diagrammatic scale developed by Kowata et al. (2010) was used to determine the percentage of injured leaf area of each leaf on the shoot.

Data analysis. Progress curves with disease incidence and severity data were plotted using the cumulative values of these variables over time to observe the behavior of the epidemic. The incidence was plotted to inform when the disease reached $100 \%$ of the leaves and severity was plotted to compare the disease amount caused by each Colletotrichum species. To plot the graphs, the cumulative incidence and severity progress curves were adjusted for defoliation (i.e., disease of a leaf that abscised was carried along until the end of the season to calculate average disease at each subsequent assessment date). The data of the average number of the monitored leaves per plot and per season were also plotted over time to indicate leaf abscission over the evaluation period.

A correlation analysis $(R)$ was performed between the number of days that each leaf remained on the plant and severity immediately before the abscission, and the correlation was considered positive at $P<0.05$.
From the severity data, the relative area under the disease progress curve (AUDPC) was calculated for each height per day. In this way, the AUDPC was calculated individually for each leaf of each shoot, and the resulting value was divided by the number of days that the leaf remained on the plant. The resulting values were summed, and the total was divided by the number of leaves evaluated. The AUDPC values at each height of the plant were submitted to an analysis of variance, taking into account the assumptions of normality and homogeneity, according to the Box-Cox method (Box and Cox 1964).

The severity data were fitted to the exponential model in the parameterization

$$
Y=y_{0} \cdot e^{-r t}
$$

where $Y$ is the disease severity, $y_{0}$ is the initial inoculum-related parameter, $r$ is the disease progression rate, and $t$ is the time in days after the first evaluation. The values of the parameter estimates were compared using Student's $t$ test $(P<0.05)$. The analyses were performed using the software R (R Core Team 2016).
A

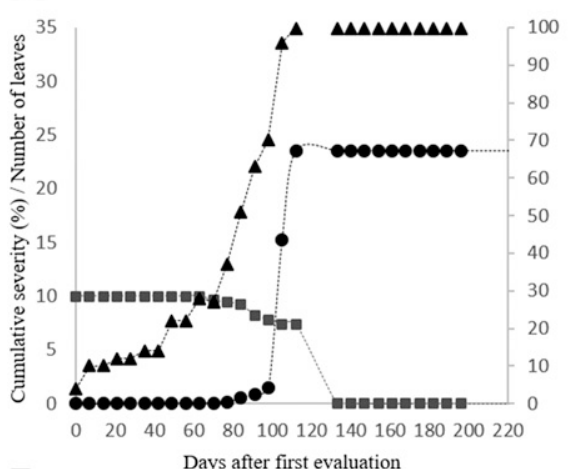

B

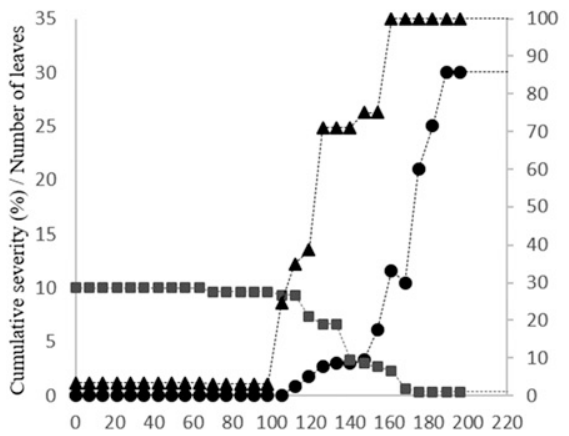

C

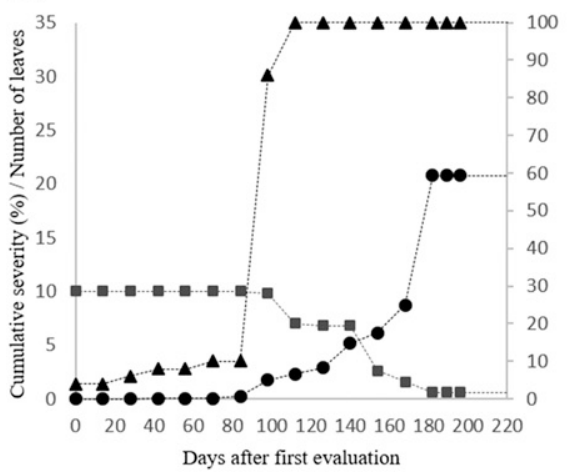

$1.0 \mathrm{~m}$

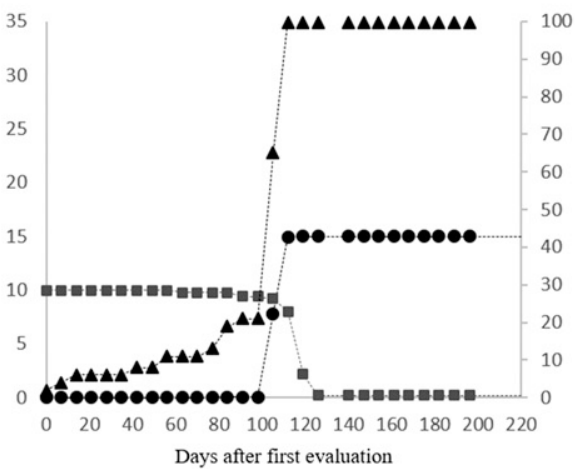

Days after first evaluation

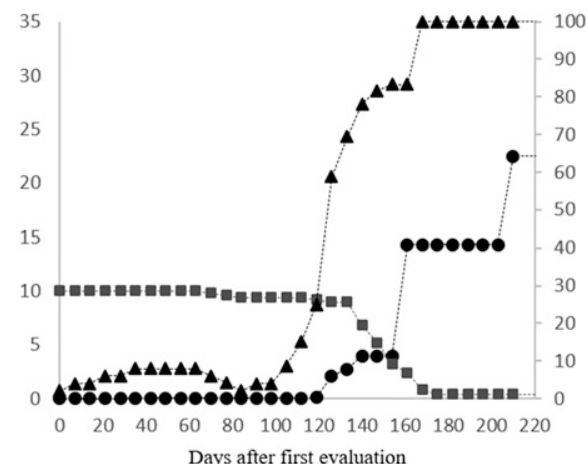

Days after first evaluation

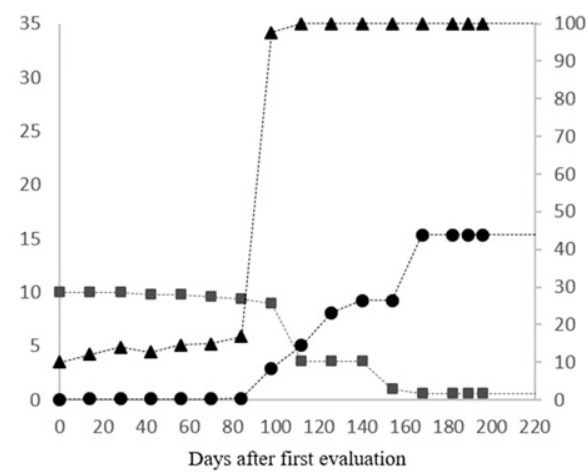

$0.3 \mathrm{~m}$
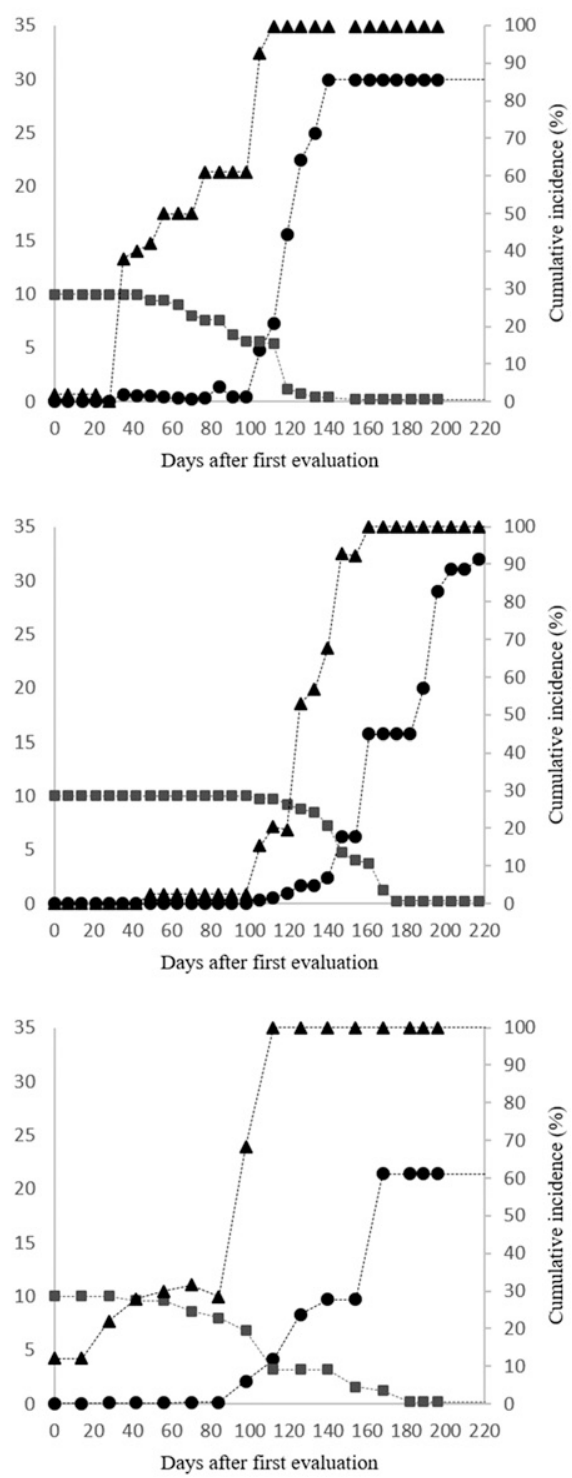

Fig. 4. Percentages of cumulative severity $(\boldsymbol{O})$ and cumulative incidence $(\boldsymbol{\Delta})$ of Glomerella leaf spot and number of apple leaves ( $\boldsymbol{\square}$ ) monitored at 1.8 (upper), 1.0 (middle), and $0.3 \mathrm{~m}$ (lower) from the ground. Data are the average of 50 leaves per height. A, Data from the 2010/2011 season in A1. B, Data from the $2010 / 2011$ season in A2. C, Data from the 2011/2012 season in A2. Plots A1 and A2 are commercial orchards in the municipality of Campo Largo and plot A3 is an experimental orchard in the municipality of Pinhais, Paraná, Brazil. The beginning of evaluation was 1 November 2010 in the 2010/2011 season in A1 and A2 and 14 November 2011 in the $2011 / 2012$ season in A2. 


\section{Results}

The rains were distributed more uniformly over time in A3 compared with A1 (Figs. 1, 2, and 3), and they were more frequent in the vegetative period than in the period of dormancy of the plants (Figs. 1C and 3C). In A2, the volumes of precipitation in 2010, 2011, and 2012 (January to April) were 1,581, 1,280, and $831 \mathrm{~mm}$, respectively (Fig. 2C). The average $\mathrm{RH}$ of the air during the period evaluated was $>80 \%$.

Spore dispersal from trunk of the tree. In the 2009/2010 season in A1 and A3, spore detection occurred before November 2009 and lasted until early April 2010 (Figs. 1A and 3A). In the 2010/2011 season in $\mathrm{A} 1$ and $\mathrm{A} 2$, detection of spores began in October and lasted until the beginning of April (Figs. 1A and 2A). In A3 in the 2010/ 2011 season, spore detection began in November and lasted until the beginning of May (Fig. 3A).

The AUPC generated from the number of spores captured in the water runoff on the trunk of the plant did not differ between the heights and between the plots, except for in A2, which differed from the others at the height of $1.0 \mathrm{~m}$ (Table 1). In A2, the concentration of conidia captured at different heights was significantly different, and it was higher at the lower height $(0.3 \mathrm{~m})$ (Table 1$)$.

Spore dispersion from the air. The presence of spores in the air at most of the evaluated plots was observed from the beginning of October and November, although in A2 and season 2011/2012, spores were observed at the end of June (beginning of winter). The spores were observed constantly until April, with occasional appearances after this time, which was the end of the vegetative phase (Figs. $1 \mathrm{~B}, 2 \mathrm{~B}$, and $3 \mathrm{~B}$ ).

The AUPC of the number of spores showed that the traps closest to the ground in all plots always had significantly higher spore numbers than those of the traps located at higher positions. In general, the traps closest to the ground ( $0.3-\mathrm{m}$ height) captured more conidia than those located at 1.0 and $2.5 \mathrm{~m}$ in the 3 years evaluated (Table 1). The

Table 2. Relative area under the disease progress curve (AUDPC) for Glomerella leaf spot (GLS), the number of days for the beginning of leaf fall (DBF), the number of days for total defoliation (DTD), the mean severity immediately before leaf fall (SBF), and the value of the correlation $\left(R^{2}\right)$ between the DTD and the $\mathrm{SBF}^{\mathrm{s}}$

\begin{tabular}{llllll}
\hline \multirow{2}{*}{$\begin{array}{l}\text { Season, plot, and } \\
\text { AUDPC }\end{array}$} & & \multicolumn{4}{c}{ Variables } \\
\cline { 3 - 4 } $2010 / 2011$ & Shoot position $^{\mathbf{u}}$ & $\mathbf{D B F}^{\mathbf{t}, \mathbf{v}}$ & $\mathbf{D T D}^{\mathbf{t}, \mathbf{v}}$ & $\mathbf{S B F}^{\mathbf{t}}$ & $\boldsymbol{R}^{\mathbf{2 v}, \mathbf{w}}$ \\
\hline A1 & & & & & \\
$1.05 \mathrm{a}^{\mathbf{x}}$ & Upper & 70 & 112 & 13.72 & $0.644^{\mathrm{y}}$ \\
$0.68 \mathrm{a}$ & Middle & 63 & 133 & 9.08 & $0.277^{\mathrm{y}}$ \\
$0.61 \mathrm{a}$ & Lower & 49 & 147 & 5.64 & $0.537^{\mathrm{y}}$ \\
$\mathrm{A} 2$ & & & & & \\
$0.72 \mathrm{a}$ & Upper & 63 & 189 & 7.02 & $0.665^{\mathrm{y}}$ \\
$0.73 \mathrm{a}$ & Middle & 63 & 210 & 9.24 & $0.490^{\mathrm{y}}$ \\
$0.87 \mathrm{a}$ & Lower & 98 & 217 & 9.38 & $0.562^{\mathrm{y}}$ \\
$2011 / 2012^{\mathrm{z}}$ & & & & & \\
$\mathrm{A} 2$ & & & & & \\
$1.01 \mathrm{a}$ & Upper & 84 & 182 & 6.20 & $0.325^{\mathrm{y}}$ \\
$1.10 \mathrm{a}$ & Middle & 28 & 168 & 5.74 & $0.589^{\mathrm{y}}$ \\
$0.82 \mathrm{a}$ & Lower & 28 & 182 & 5.46 & $0.584^{\mathrm{y}}$ \\
\hline
\end{tabular}

$\mathrm{s}$ Evaluation of GLS in two plots (A1 and A2) in the 2010/2011 season and one plot (A2) in the 2011/2012 season in leaves located in upper $(1.8 \mathrm{~m})$, middle $(1.0 \mathrm{~m})$, and lower $(0.3 \mathrm{~m})$ shoots in the municipality of Campo Largo, Paraná, Brazil.

${ }^{t}$ Mean of 50 leaves per position per divided into five shoots, with one shoot per plant.

u Upper: $\sim 1.8 \mathrm{~m}$; middle: $\sim 1.0 \mathrm{~m}$; lower: $\sim 0.3 \mathrm{~m}$.

v Counted from 11 January 2010 in A1 and A2 in 2010/2011 and from 14 November 2011 in A2 in 2011/2012.

${ }^{w}$ Calculated from the individual data of each of the 50 leaves per position per plot.

$x$ Means followed by the same letter in a column do not differ.

y Significant at $P<0.05$.

z A1 was not evaluated in the 2011/2012 season, because it was eradicated in July 2011 highest numbers of spores were observed in the months of January and February in all years assessed, regardless of the phytosanitary treatment carried out (Figs. 1B, 2B, and 3B).

In $\mathrm{A} 1$, the presence of peaks in the numbers of spores captured was observed and may have been a result of fungicide treatments as well as a smaller number of conidia within the same season compared with A3 (Fig. 3B). However, in comparing the AUPC for spore dispersion, A1 did not result in significant differences from A3 for either height $(0.3$ or $1.0 \mathrm{~m})$ (Table 1$)$.

A1, with a lower number of fungicide sprays (14) than A2 (22), had a higher number of conidia compared with A2 (Figs. 1B and 2B), which resulted in a lower AUPC in A2 at both heights (Table 1).

Temporal progression of GLS in leaves at different tree heights. In the 2010/2011 and 2011/2012 seasons for A1, the first symptoms of GLS were observed at the beginning of November and reached 50\% incidence between mid-January (beginning of harvest) and mid-February (end of harvest). In the 2010/2011 season for A2, the symptoms started in November, and the disease reached $50 \%$ incidence in the middle of March (Fig. 4).

From harvest, an exponential increase in disease severity occurred, which caused the leaves to fall with varying levels of severity depending on the position of the shoots on the plant, season, and plot (Fig. 4).

The AUDPC of GLS severity did not differ in the different positions of the shoots on the plants in both $\mathrm{A} 1$ and $\mathrm{A} 2$. In both seasons and plots, there was a positive correlation $(P<0.05)$ between the severity of the disease and the longevity of the leaves on the plant for the different positions of shoots on the plant (Table 2).

The severity data on the different plots, seasons, and heights of the plant were adjusted to the exponential model, with $R^{2}$ varying from 69 to $97 \%$ (Table 3). In the comparison of the parameter estimates, the initial inoculum $\left(y_{0}\right)$ did not differ between the different plant heights in plot A1 in the 2010/2011 season. In A2 in the 2010/2011 and 2011/2012 seasons, $y_{0}$ differed between the upper and lower thirds of the plant. The disease progress rates $(r)$ in the medium and lower shoots were lower (ranging from 0.02 to 0.05 ) and differed significantly from those of the upper shoots (ranging from 0.04 to 0.12 ) (Table 3 ).

\section{Discussion}

The dispersal of Colletotrichum species is driven mainly by water splash, because the sticky spores need water to be released. After that, wind can help to move them farther as reported in strawberry by Ntahimpera et al. (1999). In this study, a larger amount of spores was detected in slide traps located $30 \mathrm{~cm}$ from the ground. This is probably associated with a larger amount of initial inoculum

Table 3. A comparison of the epidemiological parameters with the Glomerella leaf spot severity data for different plots and seasons in the municipality of Campo Largo, Paraná, Brazil

\begin{tabular}{llll}
\hline $\begin{array}{l}\text { Season, plot, and } \\
\text { shoot position }\end{array}$ & \multicolumn{2}{c}{ Parameters } & \\
\cline { 2 - 3 } & \multicolumn{1}{c}{$\boldsymbol{y}_{\mathbf{0}}^{\mathbf{z}}$} & $\boldsymbol{r}^{\mathbf{z}}$ & \\
\hline $2010 / 2011$ & & & \\
A1 & & & \\
Upper & $0.001 \mathrm{~ns}$ & $0.12 \mathrm{a}$ & 0.95 \\
Middle & 0.02 & $0.05 \mathrm{~b}$ & 0.70 \\
Lower & 0.04 & $0.05 \mathrm{~b}$ & 0.95 \\
A2 & & & \\
Upper & $0.01 \mathrm{~b}$ & $0.04 \mathrm{a}$ & 0.97 \\
Middle & $0.08 \mathrm{ab}$ & $0.02 \mathrm{~b}$ & 0.89 \\
Lower & $0.11 \mathrm{a}$ & $0.03 \mathrm{~b}$ & 0.93 \\
2011/2012 & & & \\
A2 & & & \\
Upper & $0.001 \mathrm{c}$ & $0.05 \mathrm{a}$ & 0.97 \\
Middle & $0.18 \mathrm{~b}$ & $0.03 \mathrm{~b}$ & 0.95 \\
Lower & $0.24 \mathrm{a}$ & $0.02 \mathrm{~b}$ & 0.69 \\
\hline
\end{tabular}

y Upper: $\sim 1.8 \mathrm{~m}$; middle: $\sim 1.0 \mathrm{~m}$; lower: $\sim 0.3 \mathrm{~m}$.

${ }^{\mathrm{z}}$ Means followed by the same letter in a column do not differ significantly based on the Student's $t$ test at $P>0.05 . r=$ rate; $y_{0}=$ initial inoculum. ns $=$ not significant 
capable of reaching the lower canopy positions compared to the middle and upper positions. Corroborating this finding, Hamada and May De Mio (2017) detected the occurrence of inoculum coming from fallen leaves on the ground, and Valdebenito-Sanhueza et al. (2002) observed that the first infections of GLS generally occur in the low and inner parts of the plants.

Although collecting runoff water for spores may not represent the real situation of pathogen dissemination in the field, the observation of spores in Eppendorf traps located $1.0 \mathrm{~m}$ above the ground compared with those located at $0.3 \mathrm{~m}$ demonstrates that the pathogen may also be present in the shoots and dormant buds as previously reported for different species of the genus Colletotrichum (Børve and Stensvand 2007; Crusius et al. 2002; Kang et al. 2009). In the same orchard of this study, Hamada and May De Mio (2017) confirmed pathogenic Colletotrichum species surviving in shoots and dormant buds.

The highest amounts of conidia were observed in traps located in the canopy of the plants, but spores were also detected at $2.5 \mathrm{~m}$. In general, the spores are affected by rainfall that promoted their release and movement (Meyer et al. 2008). The intensity of precipitation can influence the kinetic energy of the droplets, which may act positively or negatively on spore dispersion (Madden et al. 1996), and it determines the distance traveled in relation to the source of inoculum.

Species of the genus Colletotrichum that are observed in subtropical regions present greater production, dissemination, and liberation of spores during the rainy seasons of the year (Freeman 2008; Mouen Bedimo et al. 2010). The main Colletotrichum species present in the study orchard belong to the $C$. acutatum complex and were pathogenic to apple leaves and fruit (Moreira et al. 2019). Weather during the trials in this study was generally favorable to the development of the epidemic, especially the amount of rain and the high $\mathrm{RH}$, which was reflected in the amount of captured spores. The higher number of spores captured in the 2009/2010 season coincided with the highest volume of accumulated precipitation observed in this season, which caused an increase in the LWP and consequently, increased the number of favorable days for the occurrence of the GLS symptoms. A lower number of spores captured in A2 may be related to the number of fungicide sprays. In A2, 22 sprays were performed, whereas in A1, there were 14 sprays, and in A3, there were 0 sprays. In addition, during the time when the GLS epidemic occurred in the field, precipitation was lower in A2 when compared with the amount of precipitation in A1 and A3, which may also have contributed to a lower spore catch.

The beginning of the onset of symptoms during the month of November coincided with the beginning of the release of spores in the air. The values of $y_{0}$ in A1 did not differ between tree heights, but for A2 in both seasons, the $y_{0}$ was higher in the lower shoots, which may be additional evidence corroborating the observations that the conidia dispersal and this $y_{0}$ are influenced by spores produced on fallen leaves on the ground. Although the disease affected the plant from initiation of fruiting (November), increase in severity was observed from January and February, and it was associated with the maintenance of weather conditions favorable for the development of the GLS and the reduction in the number of sprays during harvest because of the preharvest interval.

The AUDPC did not differ between the heights, plots, and seasons, but the GLS rate $(r)$ in the upper thirds of the trees was significantly higher. This fact may be related to that observed by Batzer et al. (2008) and Sentelhas et al. (2005); these studies reported a prolonged leaf wetness in the upper part of the plant in different crops, including apples. The GLS rate $(r)$ is an important parameter to be evaluated in this pathosystem, because the increase in symptoms is mainly owing to the secondary cycles of the pathogen in the host and not only to the initial inoculum in polycyclic diseases (Madden et al. 2007).

Incidence of GLS can promote early defoliation in apple trees (Leite et al. 1988). A positive correlation was observed in this study between the longevity of the leaves on the plant and the severity immediately before the fall for all heights and plots, but we cannot state that the early defoliation was just because of the GLS symptoms, because we did not compare with the defoliation in orchards where the GLS did not occur. Defoliation may also be related to other factors, such as stress and nutrition, and must be further investigated.

A higher initial inoculum and a greater number of spores collected on the slide traps located in the lower part of the plants may be related to the survival of the inoculum in fallen leaves on the ground; this type of survival should be investigated in future research. Primary infections quickly generate symptoms on the lower leaves, and the GLS progress increases exponentially by the rapid production of secondary inoculum under favorable conditions. The secondary inoculum is reflected in a high rate of the disease in the upper part of the plant, where the weather conditions are more favorable and where the fungicides sprays could fail.

In view of the results, it would be interesting to change the management strategy for better control of the initial inoculum, avoiding the survival of the pathogen in the leaves fallen to the ground. Other studies should investigate sprays directed to the plant base, appropriate plant density in the orchard, and the intensification of pruning for greater aeration within the canopy. Additionally, alternative controls, such as biological control, are recommended during the harvest period when no fungicide can be applied.

In our experience, forecast systems based on the monitoring of environmental conditions in the study region would not be adequate to reduce disease during growing season owing to the short incubation period of the disease and the rapid development of symptoms (Moreira et al. 2019). However, monitoring spores in the air to recommend fungicide application and research on the influence of the type of inoculum (ascospores or conidia) should be considered in future studies.

\section{Literature Cited}

Batzer, J. C., Gleason, M. L., Taylor, S. E., Koehler, K. J., and Monteiro, J. E. B. A 2008. Spatial heterogeneity of leaf wetness duration in apple trees and its influence on performance of a warning system for sooty blotch and flyspeck. Plant Dis. 92:164-170.

Becker, W. F., Katsurayama, Y., and Boneti, J. I. S. 2000. Sistema de previsão da mancha foliar da gala em macieira. Agropecu. Catarin. 17:64-67.

Becker, W. F., Katsurayama, Y., and Boneti, J. I. S. 2004. Sistema de previsão da mancha foliar-da-gala em macieira, cultivar Gala. Agropecu. Catarin. 17:64-67.

Børve, J., and Stensvand, A. 2007. Colletotrichum acutatum found on apple buds in Norway. Plant Health Prog. Online 8:1

Box, G. E. P., and Cox, D. R. 1964. An analysis transformation. J. Royal Stat. Soc. Series C Appl. Stat. 26:211-252.

Crusius, L. U., Forcelini, C. A., Sanhueza, R. M. V., and Fernandes, J. M. C. 2002 Epidemiology of apple leaf spot. Fitopatol. Bras. 27:65-70.

Estrada, A. B., Jefries, P., and Dodd, J. C. 1996. Field evaluation of a predictive model to control anthracnose disease of mango in the Philippines. Plant Pathol. 45:294-301.

Freeman, S. 2008. Management, survival strategies, and host range of Colletotrichum acutatum on strawberry. HortScience 43:66-68.

Freeman, S., Shalev, Z., and Katan, J. 2002. Survival in soil of Colletotrichum acutatum and $C$. gloeosporioides pathogenic on strawberry. Plant Dis. 86: 965-970.

Gleason, M. L., Taylor, S. E., Loughin, T. M., and Koehler, K. J. 1994. Development and validation of an empirical model to estimate duration of dew periods. Plant Dis. 78:1011-1016.

Hamada, N. A., and May De Mio, L. L. 2017. Survival of pathogenic Colletotrichum isolates on dormant buds, twigs and fallen leaves of apple trees in commercial orchards. Fruits 72:158-165.

Hamada, N. A., Nesi, C. N., Alves, G., and May De Mio, L. L. 2012. Fungicidas associados ou não a fosfitos no controle da mancha foliar de glomerella em macieira. Agraria 7 (suppl.):831-837.

Kang, B. K., Kim, J., Lee, K. H., Lim, S. C., Ji, J. J., Lee, J. W., and Kim, H. T. 2009. Effects of temperature and moisture on the survival of Colletotrichum acutatum, the causal agent of pepper anthracnose in soil and pepper fruit debris. Plant Pathol. 25:128-135.

Katsurayama, Y., and Boneti, J. I. S. 2009. Manejo das doenças de verão da macieira no sul do Brasil. Pages 45-64 in: Manejo integrado de doenças da macieira. M. J. Stadnik, ed. Universidade Federal de Santa Catarina, Florianópolis, Brazil.

Katsurayama, Y., Boneti, J. I. S., and Becker, W. F. 2000. Mancha foliar da gala: Principal doença de verão da cultura da macieira. Agropecu. Catarin. 13:14-20.

Kowata, L. S., Strapasson, M., Challiol, M. A., and May De Mio, L. L. 2010 Glomerella leaf spot in apple: Validation of proposed diagrammatic scale and efficiency of fungicides. Cienc. Rural 40:1502-1508.

Leite, R. P., Tsuneta, M., and Kishino, A. Y. 1988. Page 81 in: Ocorrência de mancha foliar de Glomerella em maicieira no estado do Paraná. Fund. Inst. Agron, Paraná, Brazil. 
Madden, L. V., Hughes, G., and Van den Bosch, F. 2007. The Study of Plant Disease Epidemics. The American Phytopathological Society, APS Press, St. Paul, Minnesota.

Madden, L. V., Yang, X., and Wilson, L. L. 1996. Effects of rain intensity on splash dispersal of Colletotrichum acutatum. Phytopathol. 86:864-874.

Meyer, J. Y., Taputuarai, R., and Killgore, E. 2008. Dissemination and impacts of the fungal pathogen, Colletotrichum gloeosporioides $\mathrm{f}$. sp. miconiae, on the invasive alien tree, Miconia calvescens. Pages 594-600 in: Proceedings of XII International Symposium on Biological Control of Weeds. M. H. Julien, R. Sforza, M. C. Bon, H. C. Evans, P. E. Hatcher, H. L. Hinz, and B. G. Rector, eds. CAB International, Wallingford, United Kingdom.

Moreira, R. R., and May De Mio, L. L. 2015. Potential biological agents isolated from apple fail to control Glomerella leaf spot in the field. Biol. Control 87:56-63.

Moreira, R. R., Peres, N. A., and May De Mio, L. L. 2019. Colletotrichum acutatum and C. gloeosporioides species complex associated with apple in Brazil. Plant Dis. 103:268-275.

Mouen Bedimo, M. J. A., Bieysse, D., Cilas, C., and Nottéghem, J. L. 2007. Spatio-temporal dynamics of arabica coffee berry disease due to Colletotrichum kahawae on a plot sacle. Plant Dis. 91:1229-1236.

Mouen Bedimo, M. J. A., Bieysse, D., Nyassé, S., Nottéghem, J. L., and Cilas, C. 2010. Role of rainfall in the development of coffee berry disease in Coffea arabica caused by Colletotrichum kahawae, in Cameroon. Plant Pathol. 59:324-329.

Ntahimpera, N., Wilson, L., Ellis, M., and Madden, L. 1999. Comparison of rain effects on splash dispersal of three Colletotrichum species infecting strawberry. Phytopathol. 89:555-563.

NTEPI. 2006. Specific Technical Guidelines for Integrated Production of Apple. Normative Instruction 1/2006 of the Secretary of Agriculture and Cooperative
Development, Ministry of Agriculture, Livestock and Supply. http:// www.agricultura.gov.br/assuntos/sustentabilidade/producao-integrada/arquivospublicacoes-producao-integrada/instrucao-normativa-no1-de-2006-ntepi-maca.pdf

Penet, L., Guyader, S., Pétro, D., Salles, M., and Bussiere, F. 2014. Direct splash dispersal prevails over indirect and subsequent spread during rains in Colletotrichum gloeosporioides infecting yams. PLoS One 9:e115757.

Petri, J. L., Leite, G. B., Couto, M., and Francescatto, P. 2011. Avanços na cultura da macieira no Brasil. Rev. Bras. Fruticultura. Special Issue:48-56.

R Core Team. 2016. R: A Language and Environment for Statistical Computing. R Foundation for Statistical Computing, Vienna, Austria.

Sentelhas, P. C., Gillespie, T. J., Batzer, J. C., Gleason, M. L., Monteiro, J. E. B. A., and Pezzopane, J. R. 2005. Spatial variability of leaf wetness duration in different crop canopies. Int. J. Biometeorol. 49:363-370.

Silva-Junior, G. J., Spósito, M. B., Marin, D. R., Ribeiro-Junior, P. J., and Amorim, L. 2014. Spatiotemporal characterization of citrus postbloom fruit drop in Brazil and its relationship to pathogen dispersal. Plant Pathol. 63:519-529.

Taylor, J. A. 1971. Necrotic leaf blotch and fruit rot of apple caused by strain of Glomerella cingulata. Phytopathology 61:221-224.

Valdebenito-Sanhueza, R. M., Becker, W., Boneti, J. I. S., Katsurayama, Y., and Czermainski, A. B. C. 2002. Manejo das Doenças de Verão na Produção Integrada de Maçã. Embrapa uva e vinho, Bento Gonçalves, Brazil.

Velho, A. C., Alaniz, S., Casanov, A. L., Mondino, P., and Stadnik, M. J. 2015. New insights into the characterization of Colletotrichum species associated with apple diseases in southern Brazil and Uruguay. Fungal Biol. 119 229-244.

Wang, C. X., Zhang, Z. F., and Li, B. H. 2012. First report of glomerella leaf spot of apple caused by Glomerella cingulata in China. Plant Dis. 96:912. 